Available online on 15.12.2020 at http://jddtonline.info
OC 2011-18, publisher and licensee JDDT, This is an Open Access article which permits
unrestricted non-commercial use(CC By-NC), provided the original work is properly cited

Open $\odot$ Access

Research Article

\title{
28 Days repeated oral toxicity study of Rosmarinus officinalis in Wistar Rats
}

\author{
S. S. Salokhe*, S. U. Kolhe, S. V. Tembhurne, Dipali Hanmghar \\ All India Shri Shivaji Memorial Society's College of Pharmacy, Kennedy Road, Near R.T.O., Pune, Maharashtra, India-411001
}

\begin{abstract}
Rosmarinus officinalis has long been used as a traditional oriental medicine. It is traditionally used as antioxidants as well as essential oil. Rosmarinus officinalis mainly contains the phenolic compounds which is responsible for the antioxidant property. In the present study, 28-day subacute oral dose toxicity studies of hydroalcoholic extracts of the plant of Rosmarinus officinalis were performed in Wistar rats. The repeated oral toxicity study was carried out to detect the no-observed adverse effect level (NOAEL). In this study, a total of 48 rats were classified into the control, low dose $(300 \mathrm{mg} / \mathrm{kg})$, medium dose $(500 \mathrm{mg} / \mathrm{kg})$ and high dose $(1000 \mathrm{mg} / \mathrm{kg})$ treatment groups. The extract was administered daily from day 1 until day 28. At the end of the study, the animals were humanely sacrificed and assessed for the effect extract of Rosmarinus officinalis plant on body weight and relative organ weights, biochemical, haematological and histopathological parameters. The biochemical parameters for the assessment of kidney and liver injuries were carried out. Results of haematological and bioche mistry results showed no changes in the control and treated groups. In the histopathology, evaluation of kidney tissues in all treated groups showed no significant $(p>0.05$ ) lesions. The results conclude that hydro-alcoholic extract of leaves Rosmarinus officinalis was found to be safe at highest dose level of $1000 \mathrm{mg} / \mathrm{kg}$ for 28 days of oral administration.
\end{abstract}

Keywords: Repeated toxicity study, Rosmarinus officinalis, biochemical analysis, histopathological study

Article Info: Received 06 Oct 2020; $\quad$ Review Completed 17 Nov 2020; $\quad$ Accepted 28 Nov 2020; Available online 15 Dec 2020

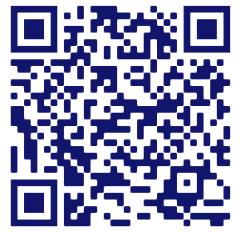

India-411001
Cite this article as:

Salokhe SS, Kolhe SU, Tembhurne SV, Hanmghar D, 28 Days repeated oral toxicity study of Rosmarinus officinalis in Wistar Rats, Journal of Drug Delivery and Therapeutics. 2020; 10(6-s):67-74 http://dx.doi.org/10.22270/jddt.v10i6-s.4616

*Address for Correspondence:

S. S. Salokhe, All India Shri Shivaji Memorial Society's College of Pharmacy, Kennedy Road, Near R.T.0., Pune, Maharashtra,

\section{INTRODUCTION:}

Medical developments have supported work that explores the creation and innovative use of medicinal plants due to their biological properties and availability at regional and around the world. A variety of natural materials are commonly used as raw materials for treatments, fitness-

conscious meals and home remedies 1,2 . Herbal extracts are believed to be more secure than chemical products. Therefore, toxicity studies of natural substances do not usually receive as much attention as studies of chemical products. However, a few natural substances are probably poisonous and can be dangerous to human health. Furthermore, issues concerning the actual safety of natural substances are constantly being discussed ${ }^{3-4}$. Therefore, systematic safety studies are also vital for compounds which can be herbal-based drug treatments or practical health ingredients.

The extract of the rosemary (Rosmarinus officinalis) contains phenolic acids (2 to $3 \%$ rosmarinic, chlorogenic, and caffeic acids), phenolic diterpenoid bitter substances (up to $4.6 \%$ carnosic acid, carnosol, rosmaridiphenol, and rosmanol), triterpenoid acids (oleanolic and ursolic acids), flavonoids (apigenin, luteolin, nepetin, and nepitrin), 1.2 to $2.5 \%$ volatile oils ( 15 to $50 \%$ 1,8-cineole, 15 to $25 \%$-pinene, 12 to $24 \%$-terpineol, 10 to $25 \%$ camphor, 5 to $10 \%$ camphene, 1 to $6 \%$ borneol, 1 to $5 \%$ bornyl acetate), and tannins $5,6,7,8$. Although phenolic diterpenes, carnosic acid, carnosol, rosmanol, and epi- and iso-rosmanol are antioxidant compounds in rosemary leaves. These extracts have been used in the treatment of arthritis, kidney damage due to diabetes, mental tiredness, fibromyalgia, gum disease (gingivitis), hypotension, opioid withdrawal etc. For the therapeutics purpose, the plant extract need to administer daily for several days and there may be safety concern for its repeated use. So in the present investigation our study was undertaken to evaluate safety profile (qualitative and quantitative examinations) of hydro-alcoholic extract of the rosemary in terms of 28 days repeated oral administration in wistar rats.

\section{MATERIAL AND METHODS:}

\section{Plant Material:}

The plant samples were collected (September 2019) in the city of Pune, state of Maharashtra, India. The plant was 
identified and authenticated by M/s. Shamantak Enterprises, Dr. Gautam, Botanist, Pune, India.

\section{Extraction:}

A weighed quantity ( $50 \mathrm{~g}$ ) of the air-dried powdered plants of R. officinalis was drawn and then it was extracted with $90 \%$ ethanol in a Soxhlet extractor. The hydroalcoholic extract was concentrated in a rotary flash evaporator at a temperature not more than $50^{\circ} \mathrm{C}$ to get a solid sticky residue. Different concentration $(300 \mathrm{mg} / \mathrm{kg}, 500 \mathrm{mg} / \mathrm{kg}$ and $1000 \mathrm{mg} / \mathrm{kg}$ p.o.) of hydroalcoholic extract of plant of $R$. officinalis was given according to body weight of animals. 3,4

\section{Animals:}

The study was undertaken at the AISSMS College of Pharmacy, Pune. The Institutional Animal Ethical Committee approved the protocol for the study. Wistar male and female rats $(150-200 \mathrm{~g})$ of about 6 months were used. They were maintained at $25 \pm 2^{\circ} \mathrm{C}$ and relative humidity of 45 to $55 \%$ and under light dark cycle (12 h light: $12 \mathrm{~h}$ dark cycle). The animals had free access to food and water ad libitum throughout study. All experiments were carried out between 9:00 - 16:00 hours.

\section{Sub- acute toxicity:}

This protocol was performed according to the Organization for Economic Cooperation and Development (OECD) Test Guidelines with slight modifications (OECD, 407). 10,11 Healthy male and female rats were randomly divided into four groups ( $\mathrm{n}=5$ /group). Animals received vehicle orally (water; control group) or Rosmarinus officinalis in doses of 300,500 and $1000 \mathrm{mg} / \mathrm{kg} /$ day for 28 consecutive days. Body weight was weekly recorded and food consumption and water intake were daily monitored. Animals were observed for signs of abnormalities during the whole treatment. At the end of the treatment, animals fasted overnight, but with water ad libitum. They were then anesthetized with pentobarbital sodium $0.035 \mathrm{~g} / \mathrm{kg}$ (i.p.) and blood samples were obtained by retro-orbital puncture, using capillary tubes for hematological and biochemical studies, with and without anticoagulant ethylenediaminetetraacetic acid (EDTA), respectively.

\section{Haematological and biochemical analysis:}

The hematological analysis was performed using an automatic hematological analyser. The parameters included: red blood cell count (RBC), white blood cell count (WBC), hemoglobin $(\mathrm{Hb})$, hematocrit $(\mathrm{Hct})$, platelet count and mean platelet volume (MPV), mean corpuscular volume (MCV), mean corpuscular hemoglobin $(\mathrm{MCH})$, mean corpuscular hemoglobin concentration (MCHC), red cell distribution width (RDW) ${ }^{11,12}$. The differential leukocyte count was performed using staining with optical microscopy and, in each case, 100 cells were counted.

In the biochemical analysis, the blood was centrifuged at $1500 \mathrm{rpm}$ for $10 \mathrm{~min}$ to obtain serum, which was stored at $-20^{\circ} \mathrm{C}$ and used for the analysis of glucose, blood urea nitrogen (BUN), creatinine, aspartate aminotransferase (AST), alanine aminotransferase (ALT), total cholesterol, triglycerides, alkaline phosphatase (ALP), total protein, albumin, total and direct bilirubin; chloride, potassium and sodium. ${ }^{14}$

\section{Histopathological Examination:}

Liver and kidneys excised from each treatment group were subjected to histopathological examinations. After fixing the tissues in $10 \%$ formalin, they were dehydrated and mounted in paraffin blocks. The sections of 3-5 $\mu$ thickness were cut and stained with hematoxylin-eosin stain.

\section{Statistical Analysis:}

Statistical analysis was carried out using the GraphPad Instat 3. All the data are shown as the mean \pm standard error of the mean (S.E.M) and were analyzed using one-way analysis of variance (ANOVA). Significant differences between the control and treatment groups were determined using Tukey - Kramer's all comparison test, $\mathrm{P}<0.05$ was considered significant.

\section{RESULT AND DISCUSSION:}

The study of subacute toxicity of the Rosmarinus officinalis extract was performed as per OECD Guideline 407. The respective oral doses $(300,500$ and $1000 \mathrm{mg} / \mathrm{kg}$ ) of hydroalcoholic extract of leaves of Rosmarinus officinalis was given for 28 days. There were no any signs of toxicity observed in any treatment group.

Table 1 depicts the effect of the Rosmarinus officinalis on the food and water intake in subacute treatment. The single daily administration of the extract at doses 300, 500 and 1000 $\mathrm{mg} / \mathrm{kg}$ for 28 days have no significant changes $(\mathrm{p}>0.05)$ in food and water intakes per animal when compared with control group.

Table 1: Effect of $R$. officinalis extract on food and water intake per animal

\begin{tabular}{|l|l|l|l|}
\hline Treatment & Sex & Average food intake (g/d) & Average water intake (mL/d) \\
\hline Control & Female & $10.67 \pm 2.54$ & \\
& Male & $16.38 \pm 2.87$ & $17.74 \pm 3.45$ \\
& Female & $13.69 \pm 2.94$ & $22.78 \pm 3.21$ \\
\hline $500 \mathrm{mg} / \mathrm{kg}$ R. officinalis & Male & $17.68 \pm 1.86$ & $15.92 \pm 2.61$ \\
& Female & $12.57 \pm 2.21$ & $24.22 \pm 3.47$ \\
\hline $1000 \mathrm{mg} / \mathrm{kg}$ R. officinalis & Female & $11.09 \pm 1.98$ & $20.64 \pm 3.43$ \\
& Male & $17.90 \pm 2.06$ & $22.68 \pm 4.29$ \\
\hline
\end{tabular}

Results are expressed as mean \pm SEM. ( $n=5$ ) Data was analyzed by one-way analysis of variance (ANOVA) followed by TukeyKramer multiple comparison test. ${ }^{*} p<0.05$. 
Table no 2 shows daily administration of Rosmarinus officinalis for 28 days did not cause any significant alteration $(p<0.05)$ in organ weights in the treatment groups relative to control group (Table 2). Results have shown that vital organs such as the liver, kidneys, heart and lungs have not been adversely affected throughout the treatment period.

Table 2: Effect of Rosmarinus officinalis extract on relative organ weight

\begin{tabular}{|l|l|l|l|l|}
\hline Group & Heart & Lungs & Liver & Kidneys \\
\hline Male & & & & \\
\hline Control & $0.53 \pm 0.06$ & $0.33 \pm 0.09$ & $3.50 \pm 1.73$ & $0.78 \pm 0.12$ \\
\hline $300 \mathrm{mg} / \mathrm{kg}$ Rosmarinus officinalis & $0.46 \pm 0.09$ & $0.29 \pm 0.06$ & $2.79 \pm 1.23$ & $0.80 \pm 0.05$ \\
\hline $500 \mathrm{mg} / \mathrm{kg}$ Rosmarinus officinalis & $0.48 \pm 0.04$ & $0.31 \pm 0.10$ & $2.50 \pm 1.50$ & $0.77 \pm 0.09$ \\
\hline $1000 \mathrm{mg} / \mathrm{kg}$ Rosmarinus officinalis & $0.50 \pm 0.09$ & $0.28 \pm 0.08$ & $2.87 \pm 1.13$ & $0.76 \pm 0.12$ \\
\hline Female & & & & \\
\hline Control & $0.48 \pm 0.09$ & $0.34 \pm 0.11$ & $3.18 \pm 1.01$ & $0.75 \pm 0.17$ \\
\hline $300 \mathrm{mg} / \mathrm{kg}$ Rosmarinus officinalis & $0.47 \pm 0.09$ & $0.32 \pm 0.11$ & $2.57 \pm 1.54$ & $0.70 \pm 0.12$ \\
\hline $500 \mathrm{mg} / \mathrm{kg}$ Rosmarinus officinalis & $0.50 \pm 0.12$ & $0.33 \pm 0.08$ & $2.74 \pm 1.87$ & $0.76 \pm 0.14$ \\
\hline $1000 \mathrm{mg} / \mathrm{kg}$ Rosmarinus officinalis & $0.47 \pm 0.13$ & $0.29 \pm 0.05$ & $2.88 \pm 1.04$ & $0.70 \pm 0.09$ \\
\hline
\end{tabular}

Results are expressed as mean \pm SEM. ( $n=5$ ) Data was analyzed by one-way analysis of variance (ANOVA) followed by Tukey-Kramer multiple comparison test. ${ }^{*} p<0.05$.

Table 3 shows the body weight of rats before, during and after the treatment. The daily oral administration of Rosmarinus officinalis at doses of 300,500 and $1000 \mathrm{mg} / \mathrm{kg}$ for 28 days did not show any significant change in body weights compared to their day 0 treatment. If any change occurs in the body weight then there is herbal extract shows significant change and shows toxicity.

Table 3: Effect of Rosmarinus officinalis extract on the body weights (g)

\begin{tabular}{|l|c|c|c|}
\hline Group & Day 0 & Day 14 & Day 28 \\
\hline Male & & & $165.18 \pm 14.03$ \\
\hline Control & $160.08 \pm 13.78$ & $162.70 \pm 13.77$ & $190.5 \pm 13.25$ \\
\hline $300 \mathrm{mg} / \mathrm{kg}$ Rosmarinus officinalis & $180.66 \pm 11.43$ & $182.16 \pm 11.76$ & $201 \pm 9.48$ \\
\hline $500 \mathrm{mg} / \mathrm{kg}$ Rosmarinus officinalis & $203.66 \pm 15.15$ & $200.33 \pm 9.92$ & $200.66 \pm 11.87^{*}$ \\
\hline $1000 \mathrm{mg} / \mathrm{kg}$ Rosmarinus officinalis & $200 \pm 8.87$ & $205.66 \pm 15.00$ & $163.5 \pm 10.72$ \\
\hline Female & & & $204.83 \pm 4.41^{*}$ \\
\hline Control & $160.87 \pm 11.60$ & $162.87 \pm 10.60$ & $190.66 \pm 3.57^{*}$ \\
\hline $300 \mathrm{mg} / \mathrm{kg}$ Rosmarinus officinalis & $200 \pm 10.52$ & $198.66 \pm 7.03^{*}$ & $200.33 \pm 8.46^{*}$ \\
\hline $500 \mathrm{mg} / \mathrm{kg}$ Rosmarinus officinalis & $190.33 \pm 10.51$ & $189.16 \pm 3.28^{*}$ & $202 \pm 8.06^{*}$ \\
\hline $1000 \mathrm{mg} / \mathrm{kg}$ Rosmarinus officinalis & $200.5 \pm 8.01$ & & \\
\hline
\end{tabular}

Results are expressed as mean \pm SEM. ( $n=5)$ Data was analysed by one-way analysis of variance (ANOVA) followed by Tukey-Kramer multiple comparison test. ${ }^{*} p<0.05$.

\section{Hematological parameters:}

The effects of the subacute oral administration of the Rosmarinus officinalis extract on hematological parameter are represented in Table 4. The evaluation of hematological parameters is of great importance in determining the health status of an individual. These parameters do not only depict the harmful effects of herbal remedies, but also reveal the blood-relating potential. We observed that there were no noticeable hemolytic changes on $\mathrm{WBC}, \mathrm{RBC}, \mathrm{Hb}, \mathrm{PCV}, \mathrm{MCH}$, MCV, MCHC, granulocytes and leukocytes ${ }^{10,11,12,13}$. The increased release of WBC's is a notable biomarker of stress and also aids in defending the body against some inflammatory conditions, such as bacterial infections, leukemia and hemorrhage. The result obtained from this study revealed that $R$. officinalis extract did not cause any significant changes in the levels of WBC count, or in their subtypes, including neutrophils, lymphocytes, monocytes and eosinophils, at any of the doses, relative to control group (Table 4). This suggests that the $R$. officinalis extract is nontoxic. 
Table 4: Effect of Rosmarinus officinalis extract on the hematological parameters.

\begin{tabular}{|c|c|c|c|c|}
\hline Parameters & Control & $200 \mathrm{mg} / \mathrm{kg}$ & $500 \mathrm{mg} / \mathrm{kg}$ & $1000 \mathrm{mg} / \mathrm{kg}$ \\
\hline \multicolumn{5}{|l|}{ Male } \\
\hline $\mathrm{Hb}(\mathrm{gm} \%)$ & $15.85 \pm 2.58$ & $20.025 \pm 2.29$ & $17.52 \pm 1.39$ & $22.85 \pm 07$ \\
\hline $\operatorname{RBC}\left(\times 10^{3} / \mathrm{cm}^{2}\right)$ & $8.61 \pm 0.23$ & $8.20 \pm 0.04$ & $6.84 \pm 0.132$ & $6.47 \pm 0.19$ \\
\hline $\mathrm{WBC}\left(\mathrm{x} 10^{3} / \mathrm{cm}^{2}\right)$ & $13.6 \pm 1.34$ & $15.7 \pm 0.17$ & $12.95 \pm 0.59$ & $14.35 \pm 1.15$ \\
\hline PLT (x 105/cm²) & $40.52 \pm 0.28$ & $41.85 \pm 0.37$ & $41.77 \pm 0.20$ & $41.17 \pm 0.43$ \\
\hline PCV (\%) & $57.24 \pm 1.67$ & $55.15 \pm 1.11$ & $58.65 \pm 0.40$ & $57.02 \pm 1.18$ \\
\hline MCV (fl) & $52.71 \pm 1.20$ & $33.67 \pm 0.80$ & $34.17 \pm 0.99$ & $34.52 \pm 0.96$ \\
\hline $\mathrm{MCH}(\mathrm{pg})$ & $17.33 \pm 0.41$ & $17.05 \pm 0.32$ & $17.77 \pm 0.16$ & $18.24 \pm 0.36$ \\
\hline $\mathrm{MCHC}(\mathrm{gm} / \mathrm{dl})$ & $666.75 \pm 16.07$ & $640.5 \pm 14.25$ & $720.75 \pm 4.88$ & $670.5 \pm 8.12$ \\
\hline Neutrophils (N \%) & $18.82 \pm 0.36$ & $21.97 \pm 0.24$ & $19.55 \pm 0.68$ & $23.55 \pm 0.51$ \\
\hline Eosinophils (E \%) & $8.08 \pm 0.17$ & $7.10 \pm 0.17$ & $6.87 \pm 0.05$ & $6.62 \pm 0.11$ \\
\hline Lymphocytes (L \%) & $12.7 \pm 0.14$ & $13.7 \pm 0.09$ & $13.7 \pm 0.18$ & $13.07 \pm 0.23$ \\
\hline Monocytes (M \%) & $41.97 \pm 0.33$ & $42.27 \pm 0.23$ & $41.3 \pm 0.40$ & $41.50 \pm 1.47$ \\
\hline \multicolumn{5}{|l|}{ Female } \\
\hline $\mathrm{Hb}(\mathrm{gm} \%)$ & $19.35 \pm 1.49$ & $22.17 \pm 0.78$ & $20.2 \pm 1.12$ & $21.72 \pm 0.21$ \\
\hline $\mathrm{RBC}\left(\mathrm{x} 10^{3} / \mathrm{cm}^{2}\right)$ & $7.00 \pm 0.09$ & $6.96 \pm 0.08$ & $6.32 \pm 0.11$ & $6.85 \pm 0.04$ \\
\hline WBC $\left(\mathrm{x} 10^{3} / \mathrm{cm}^{2}\right)$ & $11.32 \pm 1.26$ & $13.14 \pm 0.38$ & $13.20 \pm 0.35$ & $13.98 \pm 0.26$ \\
\hline PLT $\left(\times 10^{5} / \mathrm{cm}^{2}\right)$ & $42.42 \pm 0.85$ & $39.87 \pm 0.47$ & $37.07 \pm 0.53$ & $37.7 \pm 0.84$ \\
\hline PCV (\%) & $59.8 \pm 0.18$ & $60.5 \pm 0.38$ & $57.02 \pm 0.28$ & $56.92 \pm 0.20$ \\
\hline $\mathrm{MCV}(\mathrm{fl})$ & $49.8 \pm 0.52$ & $35.6 \pm 0.29$ & $35.12 \pm 1.00$ & $35.8 \pm 0.24$ \\
\hline $\mathrm{MCH}$ (pg) & $20.55 \pm 0.89$ & $21.3 \pm 0.28$ & $18.55 \pm 0.21$ & $20.09 \pm 0.07$ \\
\hline $\mathrm{MCHC}(\mathrm{gm} / \mathrm{dl})$ & $675.75 \pm 24.28$ & $678.5 \pm 21.74$ & $675.75 \pm 30.95$ & $678.5 \pm 10.89$ \\
\hline Neutrophils (N \%) & $15.9 \pm 0.27$ & $15.5 \pm 0.55$ & $15.45 \pm 1.24$ & $15.5 \pm 0.65$ \\
\hline Eosinophils (E \%) & $7.56 \pm 0.23$ & $6.47 \pm 0.08$ & $6.35 \pm 0.18$ & $6.65 \pm 0.09$ \\
\hline Lymphocytes (L \%) & $12.52 \pm 0.34$ & $12.76 \pm 0.30$ & $13.7 \pm 0.31$ & $12.67 \pm 0.11$ \\
\hline Monocytes (M \%) & $40.35 \pm 0.45$ & $37.6 \pm 0.73$ & $37.75 \pm 0.37$ & $39.52 \pm 0.38$ \\
\hline
\end{tabular}

Results are expressed as mean \pm SEM. ( $n=5)$ Data was analyzed by one-way analysis of variance (ANOVA) followed by Tukey-Kramer multiple comparison test. ${ }^{*} p<0.05$.

The effects of the subacute oral administration of the Rosmarinus officinalis on biochemical parameters are represented in Table 5.

The retention of creatinine, electrolytes, urea and uric acid in the body is indicators of kidney damage. Alteration in the levels of some electrolytes such as $\mathrm{Na}+\mathrm{K}+\mathrm{Cl}-$ and $\mathrm{Mg} 2+$ can also be a sign of renal injury or kidney disease. Our findings revealed that there was no significant difference in the level of creatinine, urea or uric acid in the three dose groups, when compared with the control group, in both sexes of the rats [14].

Any alteration in the ALT, AST and ALP parameters shows sign of the liver toxicity but in the present study results did not show any alteration in this parameter. While the results of total protein show to significant increased, these results may be because of plant extract contain protein. Hence it concludes that extract $R$. officinalis did not produce any sign or no liver toxicity whiles its 28 days oral administration. 
Table 5: Effect of Rosmarinus officinalis extract on the biochemical parameters

\begin{tabular}{|c|c|c|c|c|}
\hline Parameters & Control & $200 \mathrm{mg} / \mathrm{kg}$ & $500 \mathrm{mg} / \mathrm{kg}$ & $1000 \mathrm{mg} / \mathrm{kg}$ \\
\hline \multicolumn{5}{|l|}{ Male } \\
\hline Urea (mmol/L) & $6.22 \pm 0.20$ & $5.53 \pm 0.27$ & $5.881 \pm 0.46$ & $6 . \pm 0.31$ \\
\hline Urea Nitrogen (mmol/L) & $7.51 \pm 0.23$ & $5.44 \pm 0.22^{*}$ & $5.04 \pm 0.50^{*}$ & $5.06 \pm 0.28 *$ \\
\hline Creatinine $(\mu \mathrm{mol} / \mathrm{L})$ & $46.97 \pm 1.47$ & $40.11 \pm 2.44$ & $44.70 \pm 2.13$ & $49.45 \pm 1.59$ \\
\hline Total protein (g/L) & $78.81 \pm 2.01$ & $78.20 \pm 2.59$ & $81.52 \pm 2.38^{*}$ & $90.345 \pm 4.54^{*}$ \\
\hline Albumin (g/L) & $35.6 \pm 1.19$ & $28.66 \pm 0.99 *$ & $30.95 \pm 0.91 *$ & $32.94 \pm 0.09$ \\
\hline ALP (U/L) & $283.46 \pm 6.37$ & $279.14 \pm 0.29$ & $316.56 \pm 5.31$ & $308.89 \pm 12.98$ \\
\hline $\operatorname{AST}(\mathrm{U} / \mathrm{L})$ & $118.22 \pm 6.86$ & $120.97 \pm 5.02$ & $128.65 \pm 4.52$ & $129.58 \pm 8.26$ \\
\hline ALT (U/L) & $49.20 \pm 2.22$ & $50.39 \pm 0.87$ & $48.32 \pm 1.20$ & $53.84 \pm 1.73$ \\
\hline Bilirubin (Total) (mg/dl) & $0.50 \pm 0.04$ & $0.49 \pm 0.38$ & $0.45 \pm 0.03$ & $0.54 \pm 0.05$ \\
\hline \multicolumn{5}{|l|}{ Female } \\
\hline Urea (mmol/L) & $5.19 \pm 0.20$ & $5.58 \pm 0.17$ & $5.94 \pm 0.46$ & $6.20 \pm 0.31$ \\
\hline Urea Nitrogen (mmol/L) & $6.98 \pm 0.23$ & $5.79 \pm 0.30^{*}$ & $5.87 \pm 0.35^{*}$ & $5.43 \pm 0.21^{*}$ \\
\hline Creatinine $(\mu \mathrm{mol} / \mathrm{L})$ & $42.15 \pm 1.17$ & $41.44 \pm 1.77$ & $40.33 \pm 2.40$ & $47.77 \pm 1.14$ \\
\hline Total protein (g/L) & $69.81 \pm 1.01$ & $79.40 \pm 3.38$ & $85.48 \pm 3.96^{*}$ & $88.00 \pm 3.23^{*}$ \\
\hline Albumin (g/L) & $37.3 \pm 1.19$ & $35.84 \pm 1.31$ & $32.85 \pm 1.14$ & $33.55 \pm 0.72$ \\
\hline $\operatorname{ALP}(U / L)$ & $276.46 \pm 5.37$ & $358.89 \pm 13.70^{*}$ & $280.30 \pm 20.39$ & $240.82 \pm 9.82$ \\
\hline AST (U/L) & $120.22 \pm 6.86$ & $126.15 \pm 7.39$ & $120.97 \pm 5.19$ & $131.94 \pm 5.99$ \\
\hline ALT (U/L) & $49.20 \pm 1.22$ & $50.00 \pm 1.43$ & $52.29 \pm 0.73$ & $54.60 \pm 0.72$ \\
\hline Bilirubin (Total) (mg/dl) & $0.54 \pm 0.04$ & $0.45 \pm 0.03$ & $0.46 \pm 0.03$ & $0.68 \pm 0.04$ \\
\hline
\end{tabular}

Results are expressed as mean \pm SEM. ( $n=5)$ Data was analysed by one-way analysis of variance (ANOVA) followed by Tukey-Kramer multiple comparison test. * $p>0.05$.

\section{Histopathological Examination:}

Histological studies are used as benchmarks for determining pathological changes in tissues and organs. Histological analysis of liver and kidney revealed no abnormalities in cellular architecture of these vital organs. The results of histopathology are also supported with the results of biochemical estimation of biomarkers of liver and kidney injury which were normal in all treatment groups.

Microscopic examination of Liver from both male and female of all groups did not show any lesion of pathological significance when compared with respective control group. On the basis of histopathology findings, it can be concluded that test compound did not produce any abnormality of pathological significance.

The results of the present study conclude that hydroalcoholic extract of leaves of Rosmarinus officinalis was found to be safe at highest dose level of $1000 \mathrm{mg} / \mathrm{kg}$ for 28 days of oral administration. 


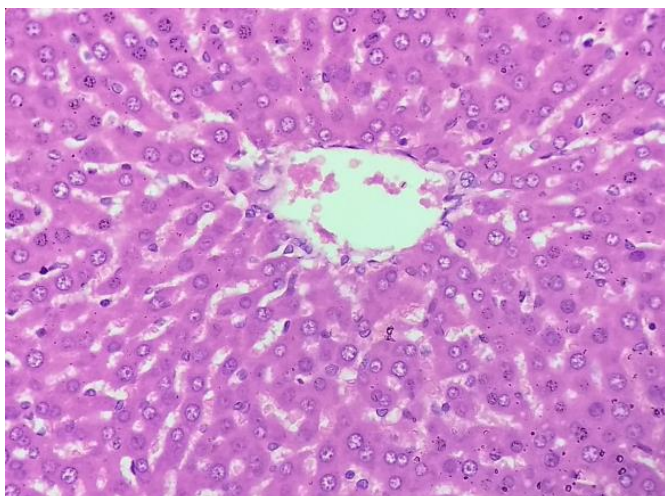

Control; Male; Liver; Showing normal periportal hepatocytes. $40 \mathrm{X}, \mathrm{H} \& \mathrm{E}$

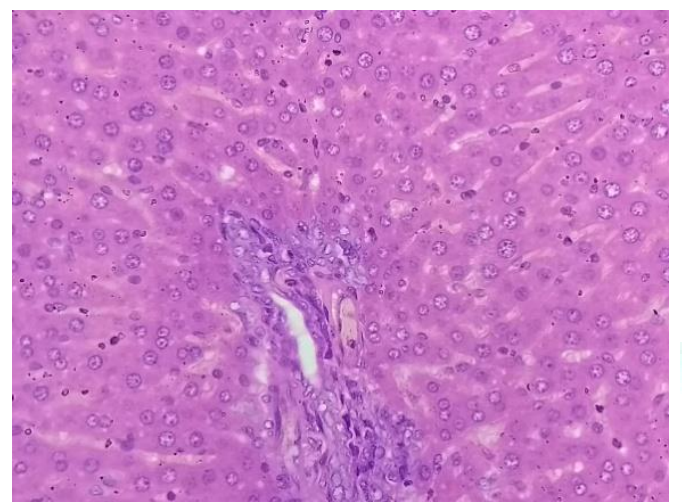

Low Dose; Male; Control; Liver; Showing normal hepatocellullar parenchyma. 40 X, H \& E

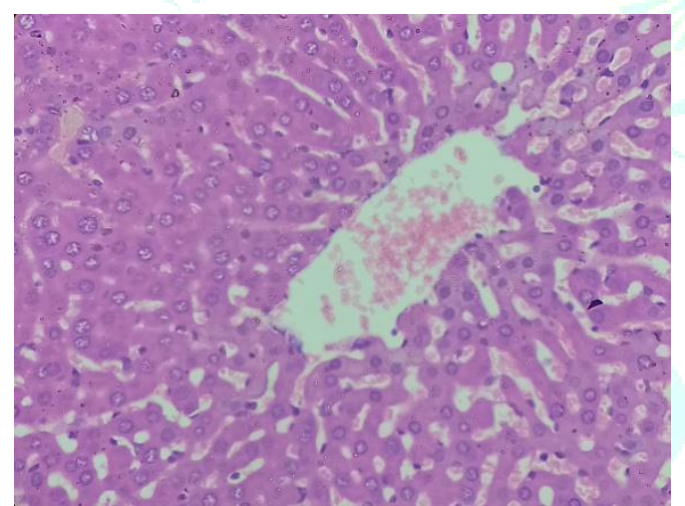

Medium Dose; Male; Liver; Showing normal hepatocellullar parenchyma

$40 \mathrm{X}, \mathrm{H} \& \mathrm{E}$

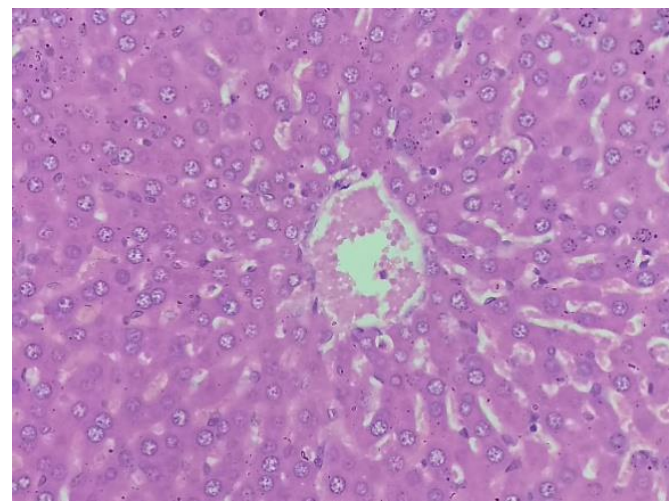

High Dose; Male; Liver; Showing normal hepatocellullar parenchyma

$40 \mathrm{X}, \mathrm{H} \& \mathrm{E}$

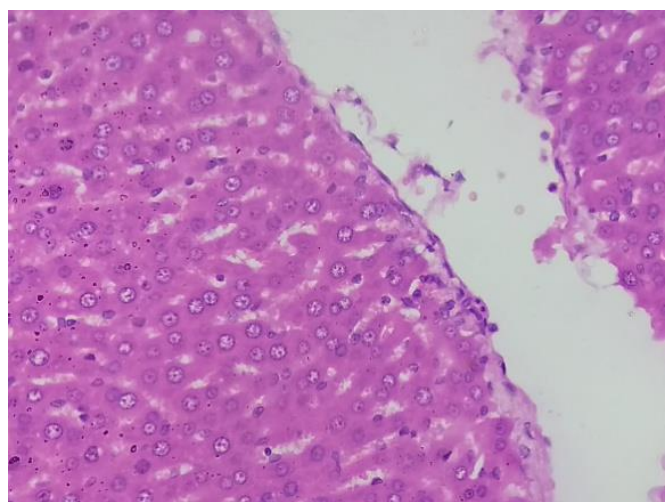

Control; Female; Liver; Showing normal

Centralobular hepatocytes. $40 \mathrm{X}, \mathrm{H} \& \mathrm{E}$

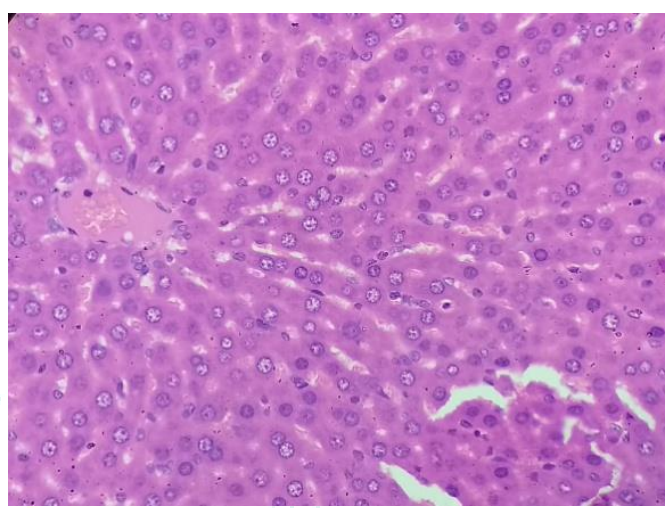

Low Dose; Female; Control; Liver; Showing normal hepatocellullar parenchyma $40 \mathrm{X}, \mathrm{H}$ \& E

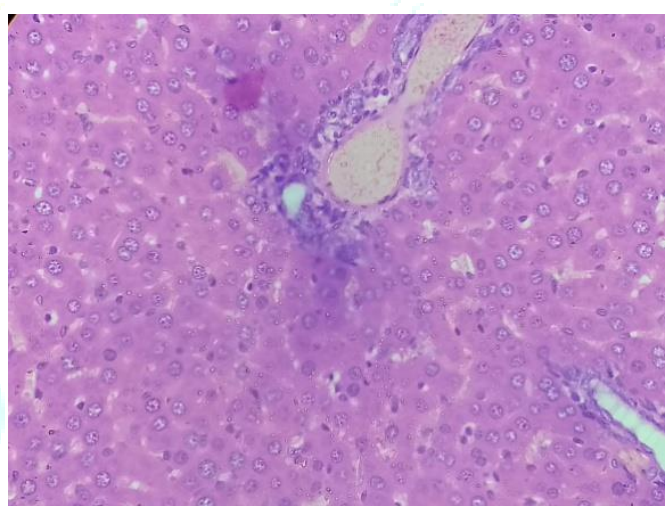

Medium Dose; Female; Liver; Showing normal hepatocellullar parenchyma

$40 \mathrm{X}, \mathrm{H} \& \mathrm{E}$

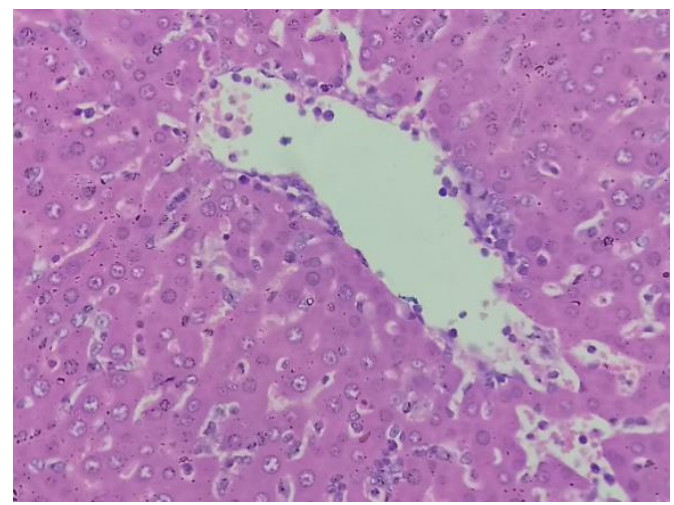

High Dose; Female; Liver; Showing normal hepatocellullar parenchyma

40 X, H \& E

Figure 1: Histopathological examination of Liver of rats in subacute oral toxicity study. 


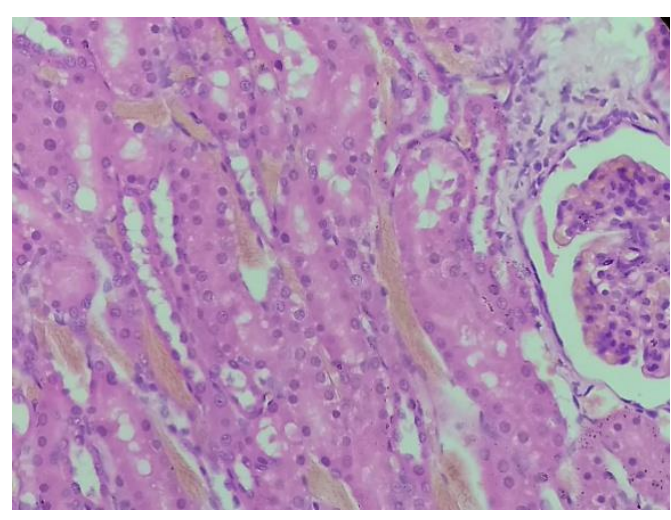

Control; Male; Kidneys; Showing normal glomerulus and tubules. $40 \mathrm{X}, \mathrm{H} \& \mathrm{E}$

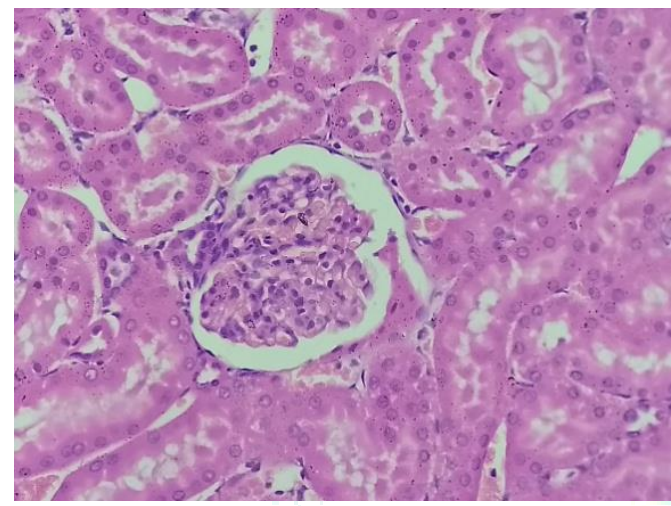

Low Dose; Male; Kidneys; Showing normal glomerulus and tubules. $40 \mathrm{X}, \mathrm{H} \& \mathrm{E}$

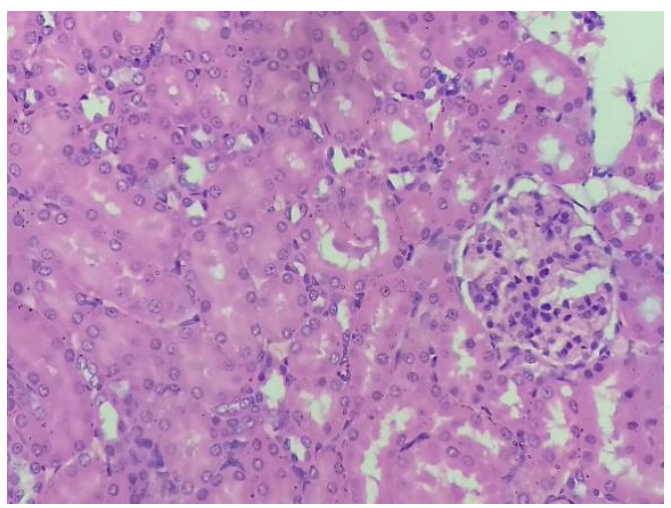

Medium Dose; Male; Kidneys; Showing normal glomerulus and tubules. $40 \mathrm{X}, \mathrm{H} \& \mathrm{E}$

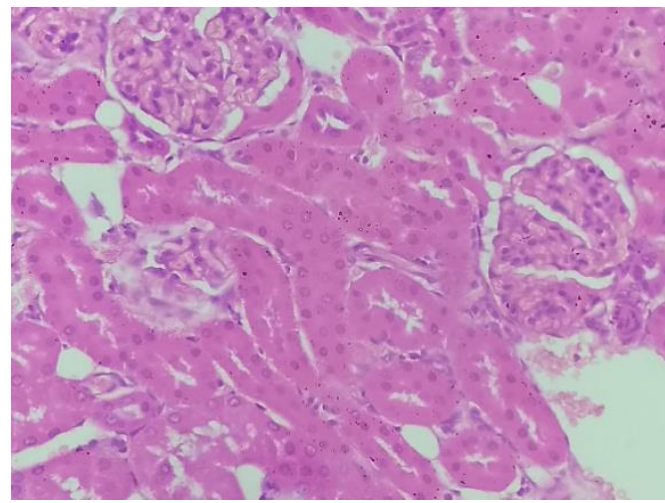

High Dose; Male; Kidneys; Showing normal glomerulus and tubules. $40 \mathrm{X}, \mathrm{H} \& \mathrm{E}$

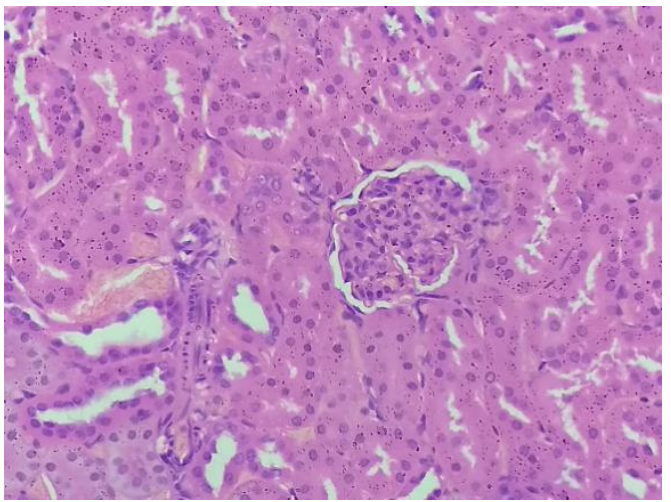

Control; Female; Kidneys; Showing normal glomerulus and tubules. $40 \mathrm{X}, \mathrm{H} \& \mathrm{E}$

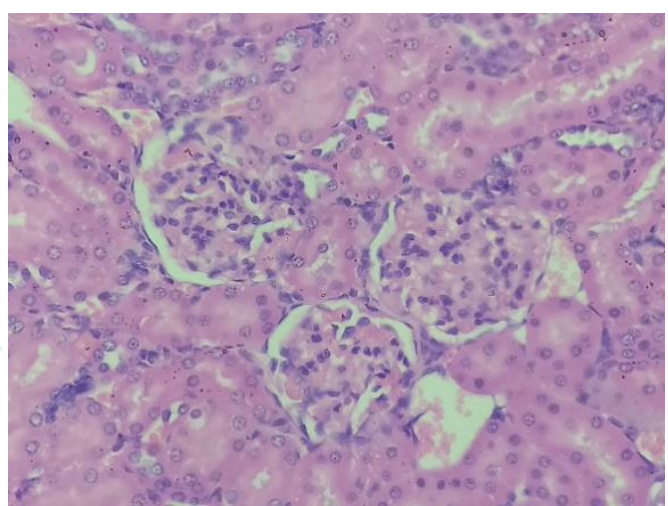

Low Dose; Female; Control; Kidneys; Showing normal glomerulus and tubules. $40 \mathrm{X}, \mathrm{H} \& \mathrm{E}$

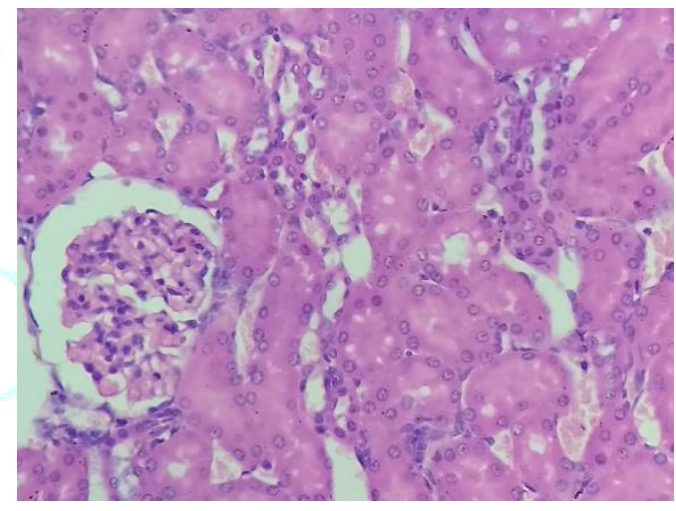

Medium Dose; Female; Kidneys; Showing normal glomerulus and tubules. $40 \mathrm{X}, \mathrm{H} \& \mathrm{E}$

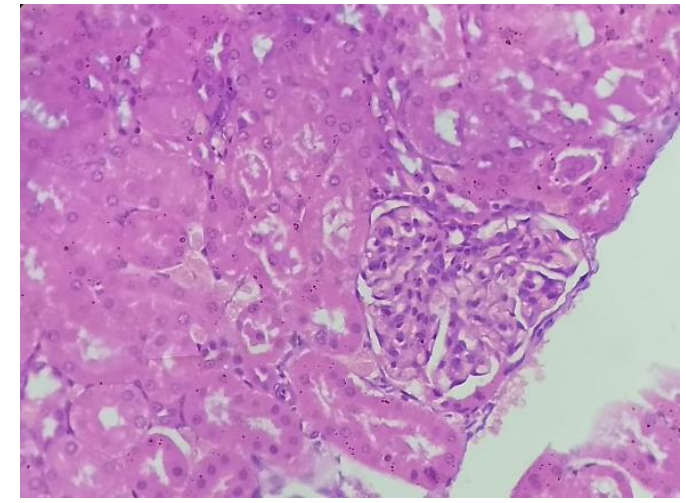

High Dose; Female; Kidneys; Showing normal glomerulus and tubules. $40 \mathrm{X}, \mathrm{H} \& \mathrm{E}$

Figure 2: Histopathological examination of Kidney of rats in subacute oral toxicity study. 


\section{ACKNOWLEDGMENTS:}

The authors would like to thankful to Principal Dr Ashwini R. Madgulkar and management of AISSMS for providing necessary infrastructure facilities to carry out the present investigation.

\section{REFERENCES:}

1. World Health Organization. WHO traditional medicine strategy. WHO; Geneva: (2s002). pp. 2002-2005.

2. Jakkula M., Boucher T.A., Beyendorff U., Conn S.M., Johnson J.E., Nolan C.J., Peine C.J., Albrecht J.H. A randomized trial of Chinese herbal medicines for the treatment of symptomatic hepatitis C. Arch. Intern. Med. 2004; 164:1341-1346.

3. Haller C.A., Benowitz N.L. Adverse cardiovascular and central nervous system events associated with dietary supplements containing ephedra alkaloids. N. Engl. J. Med. 2000; 343:18331838.

4. Pittler M.H., Ernst E. Systematic review: hepatotoxic events associated with herbal medicinal products. Aliment. Pharmacol. Ther. 2003; 18:451-471.

5. Anadón A, Martínez-Larrañaga MR, Martínez MA, Ares I, GarcíaRisco MR, Señoráns FJ, Reglero G, Acute oral safety study of rosemary extracts in rats , J Food Prot 2008 Apr; 71(4):790-5

6. Bahram R, Zahra H, Saeed EM, Marzieh RIF, Ayat K, Neuroprotective and antinociceptive effects of rosemary (Rosmarinus officinalis L.) extract in rats with painful diabetic neuropathy; The Journal of Physiological Sciences - The Physiological Society of Japan and Springer Japan KK, part of Springer Nature 2018

7. Aruoma O. I., B. Halliwell, R. Aeschbach, and J. Loligers. Antioxidant and prooxidant properties of active rosemary constituents: carnosol and carnosic acid. Xenobiotic 1992; 22:257-268.

8. Herrero M, Plaza M, Cifuentes A, Ibáñez E, Green processes for extraction of bioactives from Rosemary. Chemical and functional characterization via UPLC-MS/MS and in-vitro assays: Journal of Chromatography A 2017; 16: 2512-2520

9. Rita de Cássia da Silveira e Sá; Magda N. Leite; Leandra E.G. Oliveira; Melina M. ToledoI; Tânia C. Greggio; Martha O. Guerra Preliminary assessment of Rosmarinus officinalis toxicity on male Wistar rats' organs and reproductive system, Rev. bras. farmacogn. vol.16 no.3 João Pessoa July/Sept. 2006

10. Berhan Mengiste, Kassahun Dires, Ermias Luleka, Mahlet Arayaselassie, Tizazu Zenebe, Gezu Feleke, Eyasu Makonnen and Awol Mekonnen- Acute skin irritation, acute and sub-acute oral toxicity studies of Rosmarinus officinalis essential oils in mice and rabbit: African Journal of Pharmacy and Pharmacology, 2018; 12(26):389-396.

11. Organization for Economic Co-operation and Development (OECD) Guidance Document on Subacute Oral Toxicity Testing 407. Organization for Economic and Co-operation and Development; Paris, France, 2008

12. World Health Organization (WHO) General Guidelines for Methodologies on Research and Evaluation of Traditional
Medicine. WHO; Geneva, Switzerland, 2000; 35

13. Rosidah, Yam MF, Sadikun A, Ahmad M, Akowuah GA, Amawi MZ. Toxicology evaluation of standardized methanol extract of Gynura procumnens. J Ethnopharmacol, 2009; 123(2):244- 9.

14. Hoff-Brand AV, Pettit JE. Hematological parameters in essentials of hematology. 4th ed. New Jersey: Blackwell Science, 2000.

15. Muhammad S, Hassan LG, Dangoggo SM, Hassan SW, Umar KJ, Aliyu RU. Acute and sub chronic toxicity studies of kernel extract of Sclerocarya birrea in rats. Sci World J., 2011; 6(3):11-4.

16. Burtis CA, Ashwood ER, Bruns DE. Tietz fundamentals of clinical chemistry. 6th ed. Philadelphia: Elsevier Health Sciences; 2012: 363-8.

17. Johnson RJ, Nakagawa T, Jalal D, Sanchez-Lozada LG, Kang DH Ritz E. Uric acid and chronic kidney disease: which is chasing which? Nephrol Dial Transplant, 2013; 28(9):2221-8

18. Ruot B, Breuille D, Rambourdin F, Bayle G, Captain P, Obled C. Synthesis rate of plasma albumin is a good indicator of liver albumin synthesis in sepsis. Am J Physiol Endocrinol Metab, 2000; 279:E244-51.

19. Chung-Tack Han, Myoung-Jun Kim, Seol-Hee Moon, Yu-Rim Jeon, Jae-Sik Hwang, Chunja Nam, Chong-Woo Park, Sun-Ho Lee, JaeBum Na, Chan-Sung Park, Hee-Won Park, Jung-Min Lee1, HoSong Jang, Sun-Hee Park, Kyoung-Goo Han, Young Whan Choi Hye-Yeong Lee and Jong-Koo Kang-Acute and 28-Day Subacute Toxicity Studies of Hexane Extracts of the Roots of Lithospermum erythrorhizon in Sprague-Dawley Rats

20. Al-Sereiti MR, Abu-Amer KM, Sen P: Pharmacology of rosemary (Rosmarinus officinalis Linn.) and its therapeutic potentials. Indian J Exp Biol 1999; 37:124-130.

21. Angioni A, Barra A, Cereti E, et al.: Chemical composition, plant genetic differences, antimicrobial and antifungal activity investigation of the essential oil of Rosmarinus officinalis L. J Agric Food Chem 2004; 52:3530-3535.

22. Sachetti G, Maietti S, Muzzoli M, et al.: Comparative evaluation of 11 essential oils of different origin as functional antioxidants, antiradical and antimicrobials in foods. Food Chem 2005; 91:621-632.

23. Peana AT, D’Aquila PS, Panin F, Serra G, Pippia P, Moretti MDL: Anti-inflammatory activity of linalool and linalyl acetate constituents of essential oils. Phyto medicine 2002; 9:721-726.

24. Peana AT, D'Aquila PS, Chessa ML, Moretti MDL, Serra G, Pippia $P$ : Linalool produces antinociception in two experimental models of pain. Eur J Pharmacol 2003; 460:37-41.

25. Plaza M, Herrero M, Cifuentes A, Ibáñez E, Agric J. Food Chem. 2009; 57:7159.

26. Zhao D, Mol. Neurobiol. 2005; 31:283.

27. ARTURO ANADO' $N$, MARIA R. MARTI'NEZ-LARRAN ${ }^{\sim}$ AGA, 1 MARIA A. MARTI'NEZ, IRMA ARES, MONICA R. GARCI'A-RISCO,2 FRANCISCO J. SEN ${ }^{\sim}$ ORA $^{\prime}$ NS, AND GUILLERMO REGLERO - Acute Oral Safety Study of Rosemary Extracts in Rats; Journal of Food Protection, 2008; 71(4):790-795

28. Brand-Williams, W., M. E. Cuvelier, and C. Berset. Use of free radical method to evaluate antioxidant activity. Lebensm-Wiss. Technol. 1995; 28:25-30. 